\title{
Allenylphosphine oxides as simple scaffolds for phosphinoylindoles and phosphinoylisocoumarins
}

\author{
G. Gangadhararao, Ramesh Kotikalapudi, M. Nagarjuna Reddy \\ and K. C. Kumara Swamy*
}

\author{
Full Research Paper \\ Address: \\ School of Chemistry, University of Hyderabad, Hyderabad 500046 , \\ A. P., India. Fax: (+91)-40-23012460 \\ Email: \\ K. C. Kumara Swamy* - kckssc@uohyd.ac.in \\ * Corresponding author \\ Keywords: \\ allenes; indoles; isocoumarins; organophosphorus; \\ phosphinoyl-heterocycles; propargyl alcohols
}


has been moved to a carbon [29]. The reaction shown in Scheme $1 \mathrm{~b}$ led to rather previously unsuspected and unexpected benzazepines as products. After the elimination of a $\mathrm{CO}_{2}$ molecule, this reaction also features an unprecedented rearrangement involving the interemdiate allene [29]. Many other unusual transformations have also been reported recently [31]. In another reaction leading to phosphinoylindenone depicted in Scheme 1c, an intramolecular ene-reaction is possibly involved and in Scheme 1d the reaction led to phosphinoylisochromenes via deprotection of an allene intermediate under Lewis acid mediation [22]. In this context it was of interest to see, in a reaction like that shown in Scheme 1c, whether the introduction of an amide or a carboxylate ester in place of the - $\mathrm{CHO}$ group could lead to phosphinoyl-subtstituted indoles/isocoumarins via allenic intermediates or not. It is pertinent to note that indoles and isocoumarins are core structures found in many natural and pharmacological products [3234]. Thus in this paper, we wish to report simple synthetic routes to phosphinoylindoles, and -isocoumarins utilizing functionalized allenylphosphine oxides/allenylphosphonates.

\section{Results and Discussion}

In order to achieve the anticipated phosphinoylindoles/ isocoumarins, we prepared a variety of functionalized propargyl alcohols $\mathbf{1} \mathbf{a}-\mathbf{m}$ and $\mathbf{2 a}-\mathbf{j}$ containing an acetamide, benzamide or an ester group at the ortho position (Figure 1) [35-37]. Some of the propargyl alcohols $\mathbf{1 a}-\mathbf{c}, \mathbf{1} \mathbf{m}$ and $\mathbf{2 a}-\mathbf{j}$ were transformed to allenylphosphine oxides $\mathbf{3 a}-\mathbf{c}, \mathbf{3 m}$ and $\mathbf{4 a}-\mathbf{j}$ (Scheme 2) by following known methods [38,39].

After having several functionalized allenes in hand, initially we chose allenes $\mathbf{3 a}$ and $\mathbf{3} \mathbf{m}$ to achieve intramolecular cyclization. These were treated with $0.5 \mathrm{~mol}$ equivalents of base $\left(\mathrm{K}_{3} \mathrm{PO}_{4}\right)$ since the substrates contain active hydrogen. This reaction afforded the $N$-substituted phosphinoylindoles 5 and 7, 8 . Essentially a single isomer $\mathbf{5}$ (a dihydroindole), in which the (a)

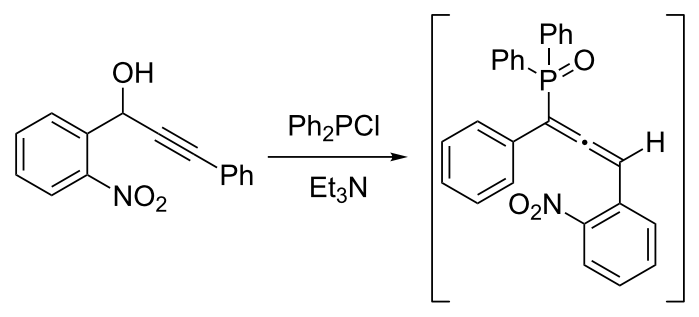

(b)

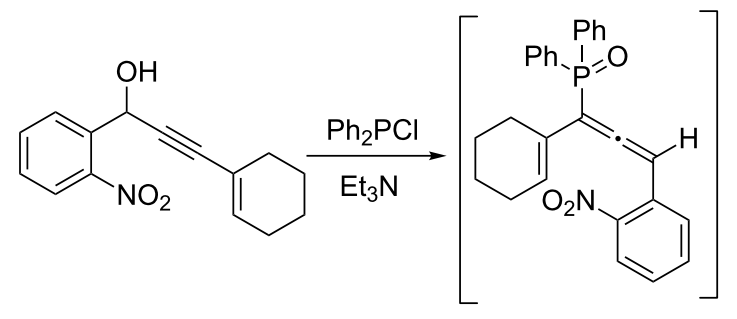

(c)<smiles>CCN(CC)CCCC(C)(C)O</smiles><smiles>CC(C)=C=C(c1ccccc1C=O)P(=O)(c1ccccc1)c1ccccc1</smiles>

(d)<smiles>CCN(CC)CCOCc1ccccc1C#CC(C)(C)O</smiles><smiles>COCc1ccccc1C(=C=C(C)C)P(=O)(c1ccccc1)c1ccccc1</smiles><smiles>Cc1cccc(C(=C2C(=O)N(O)c3ccccc32)P(=O)(c2ccccc2)c2ccccc2)c1</smiles>

phosphinoyl$N$-hydroxyindolinone<smiles>Cc1ccccc1NC1CCCC=C1P(=O)(c1ccccc1)c1ccccc1</smiles>

phosphinoylbenzazepine<smiles>CC(C)=C1C(=O)c2ccccc2C1P(=O)(c1ccccc1)c1ccccc1</smiles>

phosphinoylindenone<smiles>CC(C)C1=C(P(=O)(c2ccccc2)c2ccccc2)c2ccccc2CO1</smiles>

phosphinoylisochromene 
<smiles>[R]Nc1ccc([R])cc1C#CC([R])([R])O</smiles>

$\mathrm{R}=\mathrm{Ac}$

$R^{1}=H, R^{2}=R^{3}=M e$

$\mathrm{R}^{1}=\mathrm{H}, \mathrm{R}^{2}=\mathrm{H}, \mathrm{R}^{3}=\mathrm{Me}$

$\mathrm{R}^{1}=\mathrm{H}, \mathrm{R}^{2}=\mathrm{Me}, \mathrm{R}^{3}=\mathrm{Ph}$

$\mathrm{R}^{1}=\mathrm{H}, \mathrm{R}^{2}=\mathrm{R}^{3}=\mathrm{H}$

$R^{1}=H, R^{2}=M e, R^{3}=E t$

$\mathrm{R}^{1}=\mathrm{H}, \mathrm{R}^{2}=\mathrm{H}, \mathrm{R}^{3}=\mathrm{Ph}$

$R^{1}=H,\left(R^{2} R^{3}\right)=-\left(C_{2}\right)_{5}$

$R^{1}=M e, R^{2}=R^{3}=H$

$\mathrm{R}^{1}=\mathrm{Me}, \mathrm{R}^{2}=\mathrm{H}, \mathrm{R}^{3}=\mathrm{Me}$

$R^{1}=M e, R^{2}=H, R^{3}=P h$

$\mathrm{R}^{1}=\mathrm{Me}, \mathrm{R}^{2}=\mathrm{R}^{3}=\mathrm{Me}$

$R^{1}=M e, R^{2}=M e, R^{3}=P h$

$\mathrm{R}=\mathrm{Bz}, \mathrm{R}^{1}=\mathrm{R}^{2}=\mathrm{H}, \mathrm{R}^{3}=\mathrm{Me}$

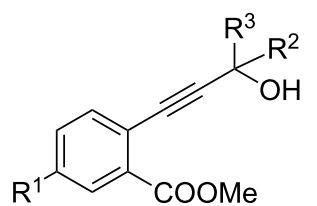

$\mathrm{R}^{1}=\mathrm{R}^{2}=\mathrm{R}^{3}=\mathrm{H}$

$R^{1}=R^{2}=H, R^{3}=M e$

(2a)

(1a)

(1b)

$\mathrm{R}^{1}=\mathrm{H}, \mathrm{R}^{2}=\mathrm{R}^{3}=\mathrm{Me}$

(1c)

(1d)

$R^{1}=H,\left(R^{2} R^{3}\right)=-\left(C_{2}\right)_{5^{-}}$

$R^{1}=R^{2}=H, R^{3}=P h$

(1e)

(1h)

$\mathrm{R}^{1}=\mathrm{H}, \mathrm{R}^{2}=\mathrm{Me}, \mathrm{R}^{3}=\mathrm{Et}$

$\mathrm{R}^{1}=\mathrm{Br}, \mathrm{R}^{2}=\mathrm{R}^{3}=\mathrm{H}$

$R^{1}=B r, R^{2}=H, R^{3}=M e$

$\mathrm{R}^{1}=\mathrm{Br}, \mathrm{R}^{2}=\mathrm{R}^{3}=\mathrm{Me}$

$R^{1}=B r,\left(R^{2} R^{3}\right)=-\left(C_{2}\right)_{5^{-}}$

Figure 1: Functionalized propargyl alcohols $1 \mathbf{a}-\mathbf{m}$ and $\mathbf{2 a - j}$ used in the present study.

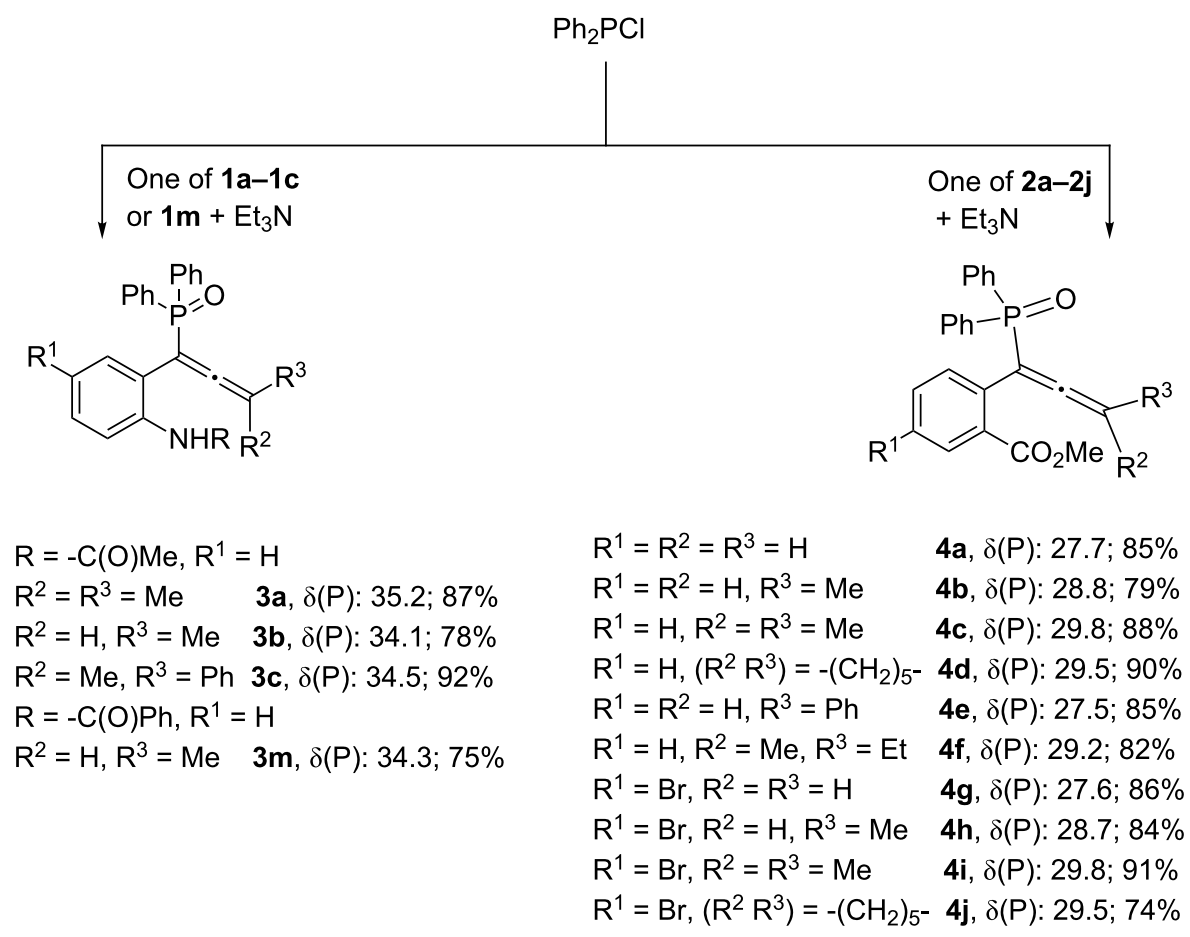

Scheme 2: Synthesis of functionalized allenes $3 a-c, 3 m$ and $4 a-j$.

$\mathrm{N}-\mathrm{H}$ proton moves only to the $\alpha$-carbon resulting in an exocyclic double bond, was formed (Scheme 3 ). The presence of a doublet for $\mathrm{PCH}$ carbon at $\delta 48.3$ with a ${ }^{1} J(\mathrm{P}-\mathrm{C})$ value of $62.0 \mathrm{~Hz}$ reveals that the phosphorus moiety is attached to an $\mathrm{sp}^{3}$-hybridized carbon. On the other hand, in the reaction using the $=\mathrm{CHMe}$ allene $\mathbf{3 m}$, two isomers in which the $\mathrm{N}-\mathrm{H}$ proton moves to either the $\alpha$-carbon (7) or the $\gamma$-carbon (8), are obtained. These two isomers can be readily distinguished by the corresponding $\delta$ and ${ }^{1} J$ values for the $\mathrm{P}-\mathrm{C}$ carbon (for $7, \delta 47.3$ and $J=62.0 \mathrm{~Hz}$; for $\mathbf{8}, \delta 106.5$ and $J=120.0 \mathrm{~Hz}$ ). Overall, the 
<smiles>CC(=O)C=C(c1ccccc1NC(C)=O)P(=O)(O)c1ccccc1</smiles>

3a<smiles>CC(C)=C(c1ccccc1NC(=O)c1ccccc1)P(=O)(c1ccccc1)c1ccccc1</smiles>

$3 m$<smiles></smiles>

5, $\delta(\mathrm{P}): 26.7 ; 92 \%$<smiles>CC#CC1=C(C)N(C(=O)c2ccccc2)c2ccccc2C1P(=O)(c1ccccc1)c1ccccc1</smiles>

7, $\delta(P): 27.3 ; 60 \%$, X-ray (ii)<smiles>CC(C)c1[nH]c2ccccc2c1P(=O)(c1ccccc1)c1ccccc1</smiles>

6, $\delta(P): 24.3 ; 93 \%$<smiles></smiles>

8, $\delta(P): 23.5 ; 31 \%$

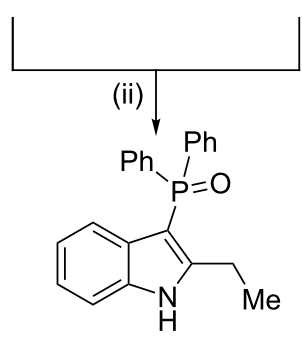

9, $\delta(P):$ 24.0; 91\%, X-ray

Scheme 3: Reaction of functionalized allenes $3 \mathrm{a}$ and $3 \mathrm{~m}$ leading to phosphinoylindoles. Conditions: (i) $\mathrm{K}_{3} \mathrm{PO}{ }_{4}(0.5 \mathrm{equiv})$, $\mathrm{THF}, 80{ }^{\circ} \mathrm{C}, 12 \mathrm{~h}$, (ii) $\mathrm{NaOH}$ (2 equiv), $\mathrm{EtOH} / \mathrm{H}_{2} \mathrm{O}(4: 1), 80^{\circ} \mathrm{C}, 8 \mathrm{~h}$.

yields of the isolated products were excellent in both cases. The structure of compound 7 was further confirmed by X-ray crystallography (Figure 2 ). The $C=C H M e$ distance of $1.317(2) \AA$ clearly indicates a double bond between these two carbon atoms. The other stereoisomer in which the methyl group is trans to the nitrogen was not observed. Interestingly though, the removal of the acyl/benzoyl group on the nitrogen in compounds $\mathbf{5}$ or $\mathbf{7 , 8}$ in aq $\mathrm{NaOH}$ afforded the 2,3-disubstituted $\mathrm{NH}$-indoles $\mathbf{6}$ or $\mathbf{9}$, respectively, in excellent yields. The $\mathrm{NH}$ band $\left(3156 \mathrm{~cm}^{-1}\right)$ in the IR spectrum and a doublet for PC carbon at $\delta 98.4\left({ }^{1} J(\mathrm{PC})=128.0 \mathrm{~Hz}\right)$ reveal the identity of compound 9. Its structure was further confirmed by X-ray crystallography (Figure 3).

Subsequently, we used aq sodium hydroxide as the base instead of $\mathrm{K}_{3} \mathrm{PO}_{4}$ (cf. conditions (ii) in Scheme 3) to perform the reaction on allene 3a. To our delight, only phosphinoyl-N $H$-indole 6 was the sole product with not even traces of 5 (Scheme 4). This shows that a strong base like sodium hydroxide effectively performs both deprotection and cyclization in a single step.

With the above conditions in hand, we then performed the reaction in one pot starting from propargyl alcohol 1a without

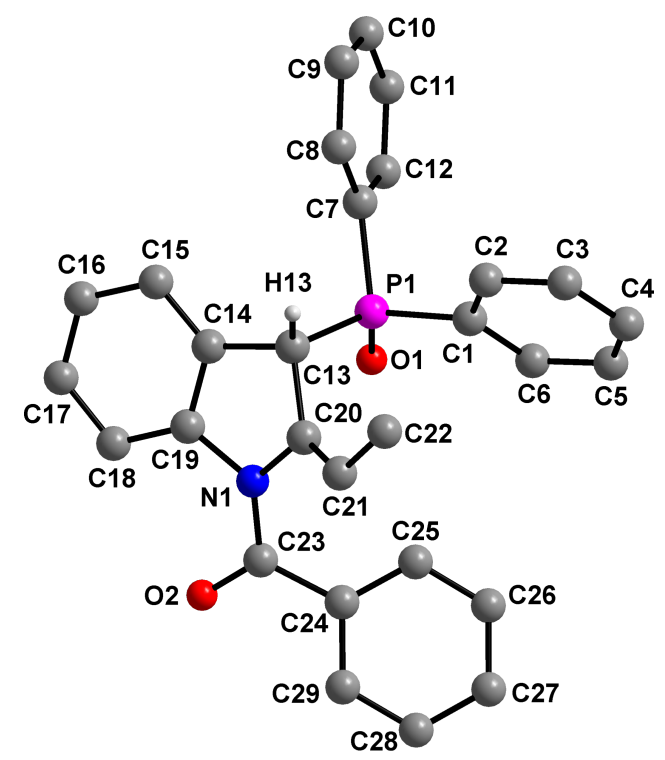

Figure 2: Molecular structure of compound 7. Hydrogen atoms (except $\mathrm{PCH})$ are omitted for clarity. Selected bond distances $(\AA)$ : P1-C13 1.8402(15), C13-C20 1.5161(19), C13-C14 1.512(2), C20-N1 1.4508(18), C20-C21 1.317(2). 


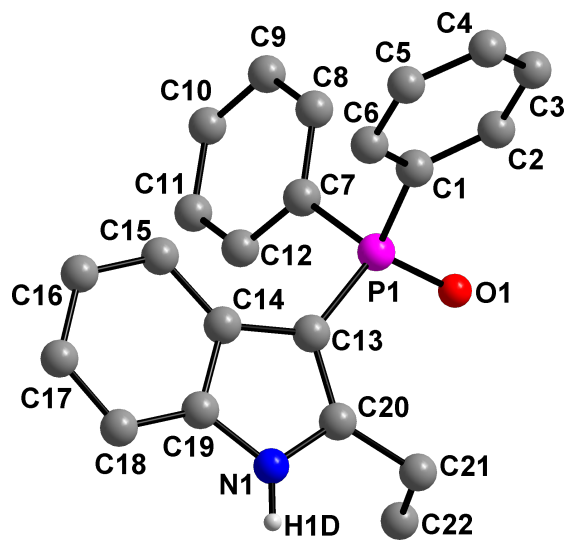

Figure 3: Molecular structure of compound 9. Hydrogen atoms (except $\mathrm{NH})$ are omitted for clarity. Selected bond distances $(\AA)$ : P1-C13 1.771(2), C13-C20 1.385(3), C13-C14 1.450(3), C20-N1 1.360(3), C20-C21 1.489(3).

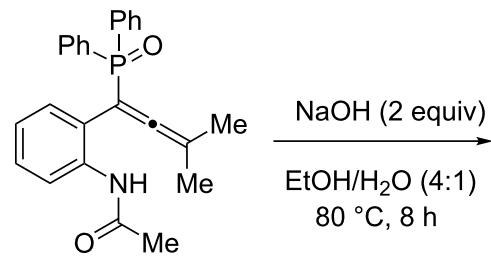

$3 \mathbf{a}$<smiles>CC(C)c1[nH]c2ccccc2c1P(=O)(c1ccccc1)c1ccccc1</smiles>

6, $89 \%$
Scheme 4: Synthesis of phosphinoylindole from allene $3 a$ in a single step.

isolating the intermediate allenylphosphine oxide 3a. Gratifyingly, the method furnished the desired product 6 in $80 \%$ yield. Inspired by this, functionalized propargyl alcohols $\mathbf{1 b}-\mathbf{l}$ were also subjected to the same one-pot conditions (Scheme 5). This one-pot strategy furnished the desired phosphinoylindoles 9-19 in good to excellent yields without any difficulty in isolation. Analogous products could also be isolated using the $\mathrm{P}$ (III) precursor $\left(\mathrm{OCH}_{2} \mathrm{CMe}_{2} \mathrm{CH}_{2} \mathrm{O}\right) \mathrm{PCl}$ (see Supporting Information<smiles>[R]c1ccc(NC(C)=O)c(C#CC([R])([R])O)c1</smiles>

(i) $\mathrm{Ph}_{2} \mathrm{PCl}, \mathrm{Et}_{3} \mathrm{~N}, \mathrm{THF}$ $0^{\circ} \mathrm{C}-\mathrm{rt}, 6-10 \mathrm{~h}$

(ii) $\mathrm{NaOH}$ (2 equiv) $\mathrm{EtOH} / \mathrm{H}_{2} \mathrm{O}(2: 1)$

$80^{\circ} \mathrm{C}, 8-10 \mathrm{~h}$ (one-pot)<smiles>CC(C)c1[nH]c2ccccc2c1P(=O)(c1ccccc1)c1ccccc1</smiles>

6, $\delta(P): 24.3 ; 80 \%$<smiles>CCC(C)c1[nH]c2ccccc2c1P(=O)(c1ccccc1)c1ccccc1</smiles>

12, $\delta(P): 24.0 ; 81 \%$<smiles>CCc1[nH]c2ccc(C)cc2c1P(=O)(c1ccccc1)c1ccccc1</smiles>

16, $\delta(P): 26.8 ; 85 \%$<smiles>CCc1[nH]c2ccccc2c1P(=O)(c1ccccc1)c1ccccc1</smiles>

9, $\delta(\mathrm{P}): 24.0 ; 78 \%$, X-ray<smiles>O=P(c1ccccc1)(c1ccccc1)c1c(Cc2ccccc2)[nH]c2ccccc12</smiles>

13, $\delta(P): 24.5 ; 63 \%$<smiles>Cc1ccc2[nH]c(Cc3ccccc3)c(P(=O)(c3ccccc3)c3ccccc3)c2c1</smiles>

17, $\delta(P): 26.6 ; 79 \%$<smiles>CC(c1ccccc1)c1[nH]c2ccccc2c1P(=O)(c1ccccc1)c1ccccc1</smiles>

$10, \delta(P): 24.3 ; 87 \%$<smiles>O=P(c1ccccc1)(c1ccccc1)c1c(C2CCCCC2)[nH]c2ccccc12</smiles>

14, $\delta(\mathrm{P}): 26.0 ; 69 \%$<smiles>Cc1ccc2[nH]c(C(C)C)c(P(=O)(c3ccccc3)c3ccccc3)c2c1</smiles>

18, $\delta(P): 24.8 ; 68 \%$<smiles>Cc1[nH]c2ccccc2c1P(=O)(c1ccccc1)c1ccccc1</smiles>

11, $\delta(P): 26.5 ; 82 \%$<smiles>Cc1ccc2[nH]c(C)c(P(=O)(c3ccccc3)c3ccccc3)c2c1</smiles>

15, $\delta(P): 26.6 ; 82 \%$<smiles>Cc1ccc2[nH]c(C(C)c3ccccc3)c(P(=O)(c3ccccc3)c3ccccc3)c2c1</smiles>

19, $\delta(P): 24.4 ; 74 \%$ 
File 1 for details). In our attmept to obtain phosphorus-free 2-alkylindole from $\mathbf{1 7}$ in the presence of triflic acid (as a solvent; $100{ }^{\circ} \mathrm{C}$ ) led to a mixture of products in which the benzyl group also was cleaved (NMR evidence). Such a reductive cleavage of the $\mathrm{P}-\mathrm{C}$ bond from phosphinoyl indoles is a reaction that we are still exploring.

A plausible pathway for the formation of phosphinoylindoles 6 and 9-19 is shown in Scheme 6. As depicted above in Scheme 2, the normal reaction of propargyl alcohol with chlorodiphenylphosphine is expected to lead to the allenylphosphine oxide. We believe that there is a subtle difference between the use of $\mathrm{K}_{3} \mathrm{PO}_{4}$ and aq $\mathrm{NaOH} . \mathrm{K}_{3} \mathrm{PO}_{4}$ abstracts the $\mathrm{NH}$ proton from allenylphosphine oxide leading to intermediate I which is followed by attack of the nitrogen lone pair on the $\beta$-carbon [24] of the allene forming addition product II or III. This upon treating with aq $\mathrm{NaOH}$ leads to the deacylated/debenzoylated phosphinoylindoles. In the one-pot reaction, though, the in situ generated allenylphosphine oxide first undergoes deacylation/debenzoylation with aq $\mathrm{NaOH}$ resulting in $-\mathrm{NH}_{2}$ functionalized allene $\mathbf{I V}$; the lone pair on nitrogen will then attack the $\beta$-carbon of the allene intramolecularly leading to phosphinoylindoles 6 or 9-19.
After succeeding in generating phosphinoylindoles, we then concentrated on synthesizing phosphinoylisocoumarins. To achieve this, we treated the functionalized allene precursors $\mathbf{4 a}-\mathbf{j}$ that are tethered with a methyl ester group, with an excess of trifluoroacetic acid at room temperature for $6 \mathrm{~h}$. Gratifyingly, this readily leds to the phosphinoylisocoumarins 20-29 (Scheme 7) in good yields. In the case of compound $\mathbf{2 5}$, as expected, both the $E$ and $Z$ isomers are present in a ratio of 1:0.65 (close $R_{\mathrm{f}}$ values). Very subtle energy differences seem to be prevalent between the dihydroisocoumains 22, 24, 25, 28, 29 and the normal isocoumarins $\mathbf{2 0}, \mathbf{2 1}, \mathbf{2 3}, \mathbf{2 6}, \mathbf{2 7}$. The former set shows a doublet in the ${ }^{1} \mathrm{H}$ NMR spectra at $\delta \sim 4.78\left({ }^{2} J(\mathrm{P}-\mathrm{H})=\right.$ $18.0 \mathrm{~Hz}, \mathrm{PCH}$ ) which is absent in the latter set; the difference in the value of ${ }^{1} J(\mathrm{P}-\mathrm{C})$ in the two sets is also consistent with the hybridization at the corresponding $\alpha$-carbon (to phosphorus). Finally, the X-ray structure was determined for 20 (Figure 4).

The above reaction is believed to proceed by the initial interaction of $\mathrm{H}^{+}$with the $\alpha, \beta$-allenic double bond to lead to $\mathbf{V}$ (Scheme 8) which on subsequent attack of oxygen of the ester group onto the $\beta$-position of allene forms VI. Intermediate VI on demethylation leads to phosphinoylisocoumarin VII. This product VII further involves the double bond isomerization to<smiles>[R]C(=O)Nc1ccc([R4])cc1/C(=C\C([R])[R])P(=O)(O)c1ccccc1</smiles><smiles>[R][R5]#[R]C</smiles>

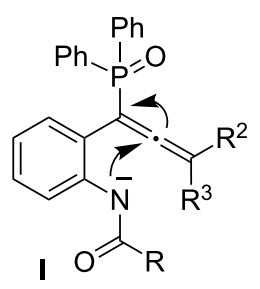<smiles>[R]C(=O)OCC(C)[C@H](C)NOO</smiles><smiles>C1CCCCC1</smiles>

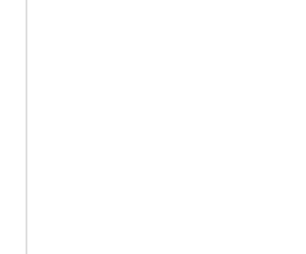

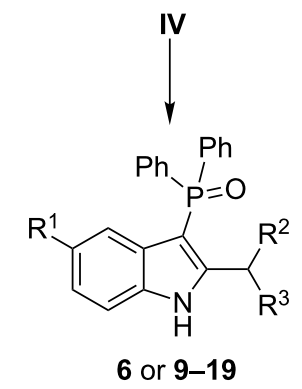<smiles>[R]C(=O)N1C(=C([R])[R])C(P(=O)(c2ccccc2)c2ccccc2)c2ccccc21</smiles><smiles>CCCCC</smiles><smiles>[R]C(=O)n1c(C([R])[R])c(P(=O)(c2ccccc2)c2ccccc2)c2ccccc21</smiles><smiles>[R20]C(C(=O)O)C(CI)CC#C</smiles> 


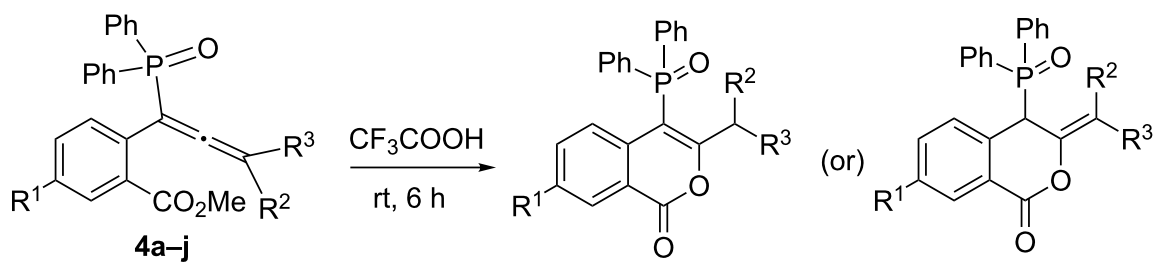<smiles>[R]c1oc(=O)c2ccccc2c1P(=O)(O)c1ccccc1</smiles><smiles>O=C1OC(=C([N+](=O)[O-])P(=O)(c2ccccc2)c2ccccc2)c2ccccc21</smiles>

22, $\delta(P): 28.7 ; 87 \%$

20, $\mathrm{R}=\mathrm{Me}, \delta(\mathrm{P}): 27.5 ; 88 \% ; \mathrm{X}$-ray 21, $\mathrm{R}=\mathrm{Et}, \delta(\mathrm{P}): 28.4 ; 82 \%$<smiles>CCC(C)=C1OC(=O)c2ccccc2C1P(=O)(c1ccccc1)c1ccccc1</smiles>

25, $E / Z \delta(P): 28.0 / 28.8 ; 86 \%$<smiles>[R]c1oc(=O)c2cc(Br)ccc2c1[P+]([O-])(O)c1ccccc1</smiles>

26, $\mathrm{R}=\mathrm{Me}, \delta(\mathrm{P}): 27.6 ; 89 \%$ 27, $R=E t, \delta(P): 27.9 ; 86 \%$<smiles>O=c1oc(C2CCCCC2)c(P(=O)(c2ccccc2)c2ccccc2)c2ccccc12</smiles>

23, $\delta(P): 28.1 ; 83 \%$<smiles>CC(C)=C1OC(=O)c2cc(Br)ccc2C1P(=O)(c1ccccc1)c1ccccc1</smiles>

28, $\delta(\mathrm{P}): 28.3 ; 92 \%$<smiles>O=C1O/C(=C\c2ccccc2)C(P(=O)(c2ccccc2)c2ccccc2)c2ccccc21</smiles>

24, $\delta(P): 29.4 ; 88 \%$<smiles>O=c1oc(C2CCCCC2)c(P(=O)(c2ccccc2)c2ccccc2)c2ccc(Br)cc12</smiles>

29, $\delta(P): 28.8 ; 85 \%$

Scheme 7: Synthesis of phosphinoylisocoumarins from functionalized allenes.

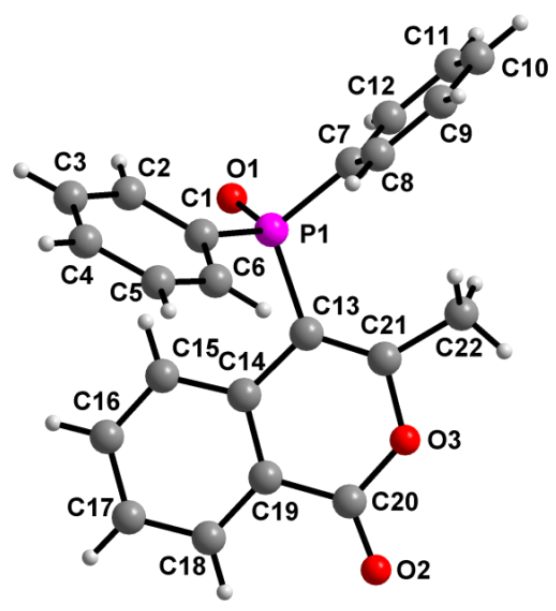

Figure 4: Molecular structure of 20 . Selected bond lengths $[\AA]$ with estimated standard deviations are given in parentheses: O3-C21 1.386(2), C21-C22 1.486(3).

lead to phosphinoyl isocoumarins 20, 21, 23, 26 and 27. The isomerization is not observed in the case of $22,24,25,28$ and 29. Alternatively, the cyclization may also proceed after the hydrolysis of ester group to $-\mathrm{COOH}$ due to the presence of adventitious moisture in trifluoroacetic acid.
When the above reaction was performed in wet trifluoroacetic acid $\left(\mathrm{TFA} / \mathrm{H}_{2} \mathrm{O}=20: 1\right)$ at $70{ }^{\circ} \mathrm{C}$, phosphinoylisocoumarins were formed in all cases, but additionally, phosphorus-free isocoumarins 30-35 (Scheme 9) [37] are also formed in the reaction using terminally substituted allenes $\mathbf{4 b}-\mathbf{d}$ and $\mathbf{4 h}-\mathbf{j}$. We have also determined the X-ray structure of compound $\mathbf{3 3}$ (Figure 5) for final confirmation. It is possible that isocoumarins 30-35 are formed via the intermediates VIII-IX (Scheme 10) [40]. The phosphorus moiety of IX may then be cleaved as $\mathrm{Ph}_{2} \mathrm{POOH}$ to form the phosphorus-free isocoumarins. Since this was not the interest in the present study, we did not proceed further.

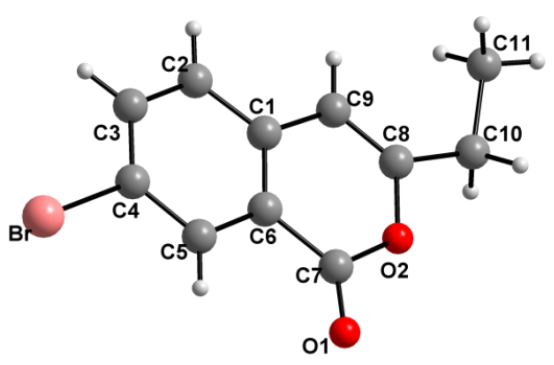

Figure 5: Molecular structure of 33. Selected bond lengths $[\AA]$ with estimated standard deviations are given in parentheses: $\mathrm{O} 2-\mathrm{C} 8$ 1.377(6), C8-C10 1.492(6). 
<smiles>[R]C(=O)c1cc([R])ccc1C(=C(C(=O)O)P(=O)(c1ccccc1)c1ccccc1)C([R])([R])[2H]</smiles>

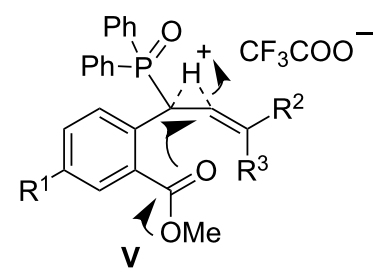<smiles>[R]c1ccc2c(P(=O)(c3ccccc3)c3ccccc3)c(C([R])[R])oc(=O)c2c1</smiles>

$(20,21,23,26,27)$ (or)<smiles>[R]C([R])=C1OC(=O)c2cc([R])ccc2C1P(=O)(c1ccccc1)c1ccccc1</smiles><smiles>[R]C([R])=C1OC(=O)c2cc([R])ccc2C1P(=O)(c1ccccc1)c1ccccc1</smiles>

Scheme 8: Possible pathway for the formation of phosphinoylisocoumarins.

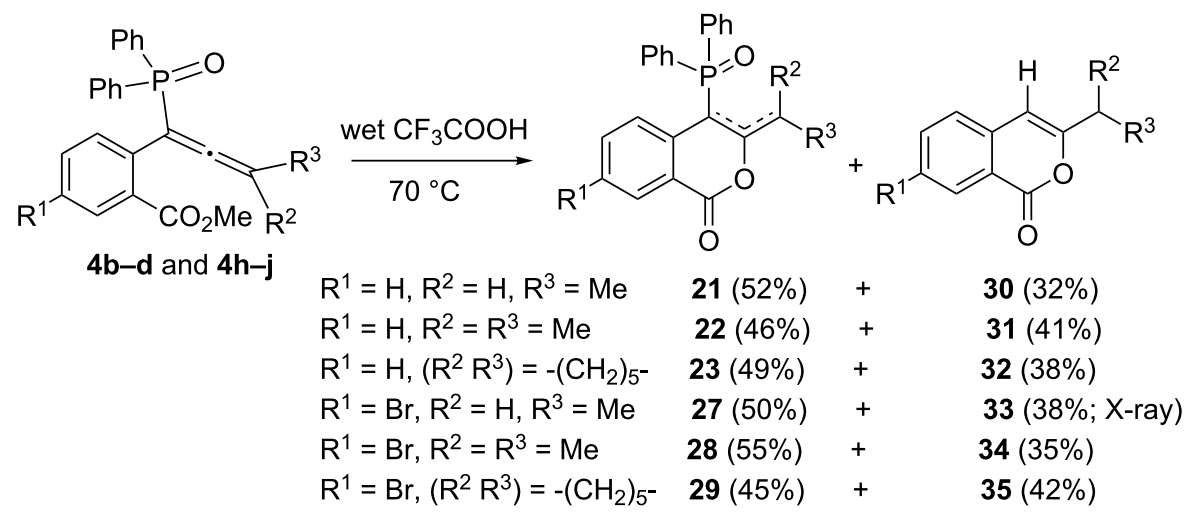

Scheme 9: Reaction of allenes in wet trifluoroacetic acid.

\section{Conclusion}

A fairly simple route to phosphinoylindoles and phosphinoylisocoumarins starting from functionalized propargyl alcohols via allenyl phosphine oxide is developed. The first reaction involves base-mediated deprotection and cyclization while the latter methodology involves acid mediation in which trifluoroacetic acid acts as the reagent as well as the solvent.

\section{Experimental}

Details on the synthesis of the compounds $\mathbf{1 a}-\mathbf{1} \mathbf{m}, \mathbf{2 a}-\mathbf{2} \mathbf{j}$, $\mathbf{3 a}-\mathbf{3 c}, \mathbf{3 m}, \mathbf{4 a - 4 j}$ and $\mathbf{5}-\mathbf{3 5}$ are given in Supporing Information File 1.

Crystallographic data for the structures of 7, 9, 20 and $\mathbf{3 3}$ have been deposited with the Cambridge Crystallographic Data Centre as supplementary publication number CCDC
981067-981070. Copies of the data can be obtained free of charge, on application to CCDC, 12 Union Road, Cambridge CB2 1EZ, UK [fax: +44(1223)336033 or e-mail: deposit@ccdc.cam.ac.uk]. The structures were solved and refined by standard methods [41-43].

7: Colorless block, $\mathrm{C}_{29} \mathrm{H}_{24} \mathrm{NO}_{2} \mathrm{P}, M=449.46$, monoclinic, space group $P 2{ }_{1} / \mathrm{c}, a=9.9427(15), b=16.894(3), c=$ 14.819(2) $\AA, \alpha=90.00, \beta=109.195(2), \gamma=90.00^{\circ}, V=$ 2350.8(6) $\AA^{3}, Z=4, \mu=0.143 \mathrm{~mm}^{-1}$, data/restrains/parameters: $4141 / 0 / 299, \mathrm{R}$ indices $(\mathrm{I}>2 \sigma(\mathrm{I})): \mathrm{R} 1=0.0408, w \mathrm{R} 2($ all data $)=$ 0.1101. CCDC no. 981067.

9: Colorless block, $\mathrm{C}_{22} \mathrm{H}_{20} \mathrm{NOP}, M=345.36$, orthorhombic, space group Pccn, $a=11.2497(6), b=21.1287(9), c=$ 15.2880(6) $\AA, \alpha=90, \beta=90, \gamma=90^{\circ}, V=3633.8(3) \AA^{3}, Z=8$, 


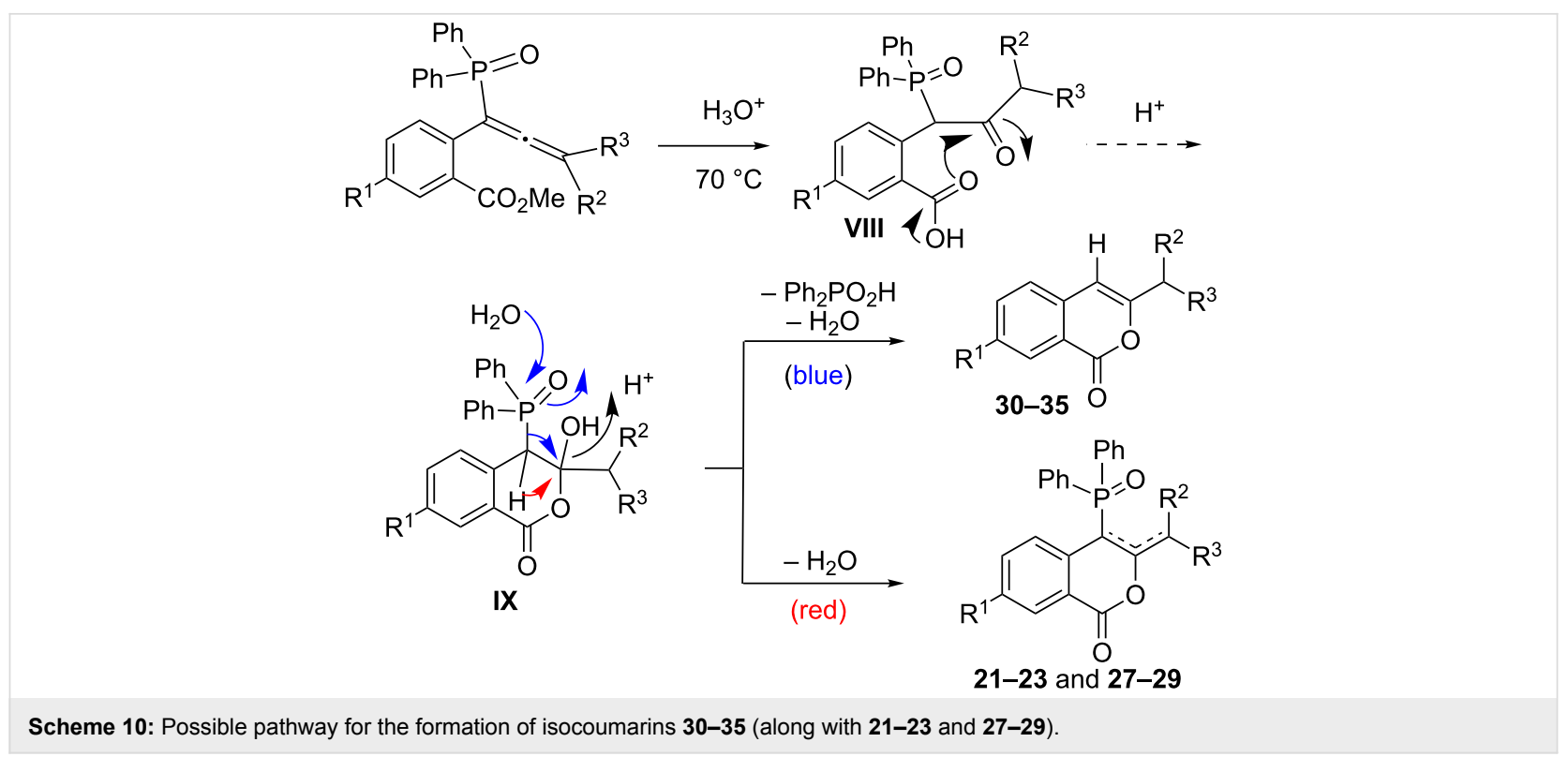

$\mu=0.160 \mathrm{~mm}^{-1}$, data/restrains/parameters: $3205 / 0 / 231, \mathrm{R}$ indices $(\mathrm{I}>2 \sigma(\mathrm{I})): \mathrm{R} 1=0.0430, w \mathrm{R} 2($ all data $)=0.1076 . \mathrm{CCDC}$ no. 981068 .

20: Colorless block, $\mathrm{C}_{22} \mathrm{H}_{17} \mathrm{O}_{3} \mathrm{P}, M=360.33$, triclinic, space group $P \overline{1}, a=9.7440(19), b=9.9918(17), c=10.2864(18) \AA, \alpha$ $=84.229(14), \beta=76.556(16), \gamma=66.323(18)^{\mathrm{o}}, V=892.0(3) \AA^{3}$, $Z=2, \mu=0.173 \mathrm{~mm}^{-1}$, data/restrains/parameters: $3647 / 0 / 236$, $\mathrm{R}$ indices $(\mathrm{I}>2 \sigma(\mathrm{I})): \mathrm{R} 1=0.0455, w \mathrm{R} 2($ all data $)=0.1114$ CCDC no. 981069.

33: Colorless needles, $\mathrm{C}_{11} \mathrm{H}_{9} \mathrm{BrO}_{2}, M=253.09$, triclinic, space group $P \overline{1}, a=7.9413(19), b=7.9674(19), c=9.746(2) \AA, \alpha=$ 66.05(2), $\beta=79.379(19), \gamma=62.93(2)^{\mathrm{o}}, V=501.8(2) \AA^{3}, Z=2$, $\mu=4.064 \mathrm{~mm}^{-1}$, data/restrains/parameters: 1354/0/128, R indices $(\mathrm{I}>2 \sigma(\mathrm{I})): \mathrm{R} 1=0.0425, w \mathrm{R} 2$ (all data) $=0.1021$. CCDC no. 981070 .

\section{Supporting Information}

\section{Supporting Information File 1}

Details on the synthesis and characterization of the compounds $1 \mathbf{a}-\mathbf{1 m}, \mathbf{2 a}-\mathbf{2 j}, \mathbf{3 a}-\mathbf{3 c}, \mathbf{3 m}, \mathbf{4 a}-\mathbf{4 j}$ and $5-35$ and ${ }^{1} \mathrm{H} /{ }^{13} \mathrm{C}$ NMR spectra of new compounds (including $\mathbf{A}-\mathbf{B}$ ). [http://www.beilstein-journals.org/bjoc/content/ supplementary/1860-5397-10-99-S1.pdf]

\section{Supporting Information File 2}

CIF file for the compounds 7, 9, 20 and 33 .

[http://www.beilstein-journals.org/bjoc/content/ supplementary/1860-5397-10-99-S2.cif]

\section{Acknowledgements}

We thank the Department of Science and Technology (DST, New Delhi) for financial support and the Single Crystal X-ray diffractometer facility, and the University Grants Commission (UGC, New Delhi) for equipment under UPE and CAS programs. G.G., R.K., M.N.R. thank the Council of Scientific and Industrial Research (CSIR, New Delhi) for fellowship. K.C.K.S. thanks DST for the J. C. Bose fellowship.

\section{References}

1. Krause, N.; Hashmi, A. S. K., Eds. Modern Allene Chemistry; Wiley-VCH: Weinheim, 2004; pp 760-787.

2. Brummond, K. M.; DeForrest, J. E. Synthesis 2007, 795 . doi:10.1055/s-2007-965963

3. Hoffmann-Röder, A.; Krause, N. Angew. Chem., Int. Ed. 2004, 43, 1196. doi:10.1002/anie.200300628

4. Rivera-Fuentes, P.; Diederich, F. Angew. Chem., Int. Ed. 2012, 51, 2818. doi:10.1002/anie.201108001

5. Ma, S. Chem. Rev. 2005, 105, 2829. doi:10.1021/cr020024j

6. Alcaide, B.; Almendros, P.; Aragoncillo, C. Chem. Soc. Rev. 2010, 39, 783. doi:10.1039/b913749a

7. Yu, S.; Ma, S. Angew. Chem., Int. Ed. 2012, 51, 3074. doi:10.1002/anie.201101460

8. Krause, N.; Winter, C. Chem. Rev. 2011, 111, 1994 doi:10.1021/cr1004088

9. Pinho e Melo, T. M. V. D. Monatsh. Chem. 2011, 142, 681. doi:10.1007/s00706-011-0505-7

10. Beccalli, E. M.; Bernasconi, A.; Borsini, E.; Broggini, G.; Rigamonti, M.; Zecchi, G. J. Org. Chem. 2010, 75, 6923. doi:10.1021/jo101501u

11. Poonoth, M.; Krause, N. J. Org. Chem. 2011, 76, 1934. doi:10.1021/jo102416e

12. Inuki, S.; Iwata, A.; Oishi, S.; Fujii, N.; Ohno, H. J. Org. Chem. 2011, 76, 2072. doi:10.1021/jo102388e

13. Cheng, J.; Jiang, X.; Ma, S. Org. Lett. 2011, 13, 5200. doi:10.1021/ol202074e 
14. Szeto, J.; Sriramurthy, V.; Kwon, O. Org. Lett. 2011, 13, 5420. doi:10.1021/ol201730q

15. Scheufler, F.; Maier, M. E. Eur. J. Org. Chem. 2000, 3945. doi:10.1002/1099-0690(200012)2000:23<3945::AID-EJOC3945>3.0.C 0;2-6

16. Jiang, X.; Kong, W.; Chen, J.; Ma, S. Org. Biomol. Chem. 2008, 6, 3606. doi:10.1039/b808767a

17. Sajna, K. V.; Kotikalapudi, R.; Chakravarty, M.; Kumar, N. N. B.; Kumara Swamy, K. C. J. Org. Chem. 2011, 76, 920. doi:10.1021/jo102240u

18. Moonen, K.; Laureyn, I.; Stevens, C. V. Chem. Rev. 2004, 104, 6177. doi:10.1021/cr030451c

19. McGrath, J. W.; Chin, J. P.; Quinn, J. P. Nat. Rev. Microbiol. 2013, 11, 412. doi:10.1038/nrmicro3011

20. Tang, W.; Zhang, X. Chem. Rev. 2003, 103, 3029 doi:10.1021/cr020049i

21. Chakravarty, M.; Kumara Swamy, K. C. J. Org. Chem. 2006, 71, 9128. doi:10.1021/jo061525y

22. Sajna, K. V.; Kumara Swamy, K. C. J. Org. Chem. 2012, 77, 5345. doi:10.1021/jo300705f

23. Chakravarty, M.; Bhuvan Kumar, N. N.; Sajna, K. V.; Kumara Swamy, K. C. Eur. J. Org. Chem. 2008, 4500. doi:10.1002/ejoc. 200800490

24. Bhuvan Kumar, N. N.; Nagarjuna Reddy, M.; Kumara Swamy, K. C. J. Org. Chem. 2009, 74, 5395. doi:10.1021/jo900896v

25. Phani Pavan, M.; Nagarjuna Reddy, M.; Bhuvan Kumar, N. N.; Kumara Swamy, K. C. Org. Biomol. Chem. 2012, 10, 8113. doi:10.1039/c2ob26285a

26. Sajna, K. V.; Kumara Swamy, K. C. J. Org. Chem. 2012, 77, 8712. doi:10.1021/jo301694n

27. Srinivas, V.; Sajna, K. V.; Kumara Swamy, K. C. Tetrahedron Lett. 2011, 52, 5323. doi:10.1016/j.tetlet.2011.08.020

28. Rama Suresh, R.; Kumara Swamy, K. C. J. Org. Chem. 2012, 77, 6959. doi:10.1021/jo301149s

29. Srinivas, V.; Sajna, K. V.; Kumara Swamy, K. C. Chem. Commun. 2011, 47, 5629. doi:10.1039/c1cc10230c

30. Phani Pavan, M.; Kumara Swamy, K. C. Synlett 2011, 1288. doi:10.1055/s-0030-1260533

31. Gangadhararao, G.; Kumara Swamy, K. C. Tetrahedron 2014, 70, 2643. doi:10.1016/j.tet.2014.02.064

32. Kochanowska-Karamyan, A. J.; Hamann, M. T. Chem. Rev. 2010, 110, 4489. doi:10.1021/cr900211p

33. Kaushik, N. K.; Kaushik, N.; Attri, P.; Kumar, N.; Kim, C. H.; Verma, A. K.; Choi, E. H. Molecules 2013, 18, 6620. doi:10.3390/molecules18066620

34. Pal, S.; Chatare, V.; Pal, M. Curr. Org. Synth. 2011, 15, 782. doi:10.2174/138527211794518970

35. Chincilla, R.; Nájera, C. Chem. Soc. Rev. 2011, 40, 5084. doi:10.1039/c1cs15071e

36. Roesch, K. R.; Larock, R. C. J. Org. Chem. 2002, 67, 86. doi:10.1021/jo010579z

37. Mikhailovskaya, T. F.; Vasilevsky, S. F. Russ. Chem. Bull. 2010, 59, 632. doi:10.1007/s11172-010-0133-0

38. Schuster, H. F.; Coppola, G. M. Allenes in Organic Synthesis; Wiley: New York, NY, 1984; pp $247 \mathrm{ff}$.

39. Lang, R. W.; Hansen, H.-J. Organic Synthesis; Collect. Vol. 7; Wiley \& Sons: New York, 1990; p 232.

40. Kumara Swamy, K. C.; Satish Kumar, N. Acc. Chem. Res. 2006, 39, 324. doi:10.1021/ar050188x

(A review on pentacoordinated phosphorus).
41. Sheldrick, G. M. SADABS, Siemens Area Detector Absorption Correction; University of Göttingen: Germany, 1996.

42. Sheldrick, G. M. SHELX-97: A program for crystal structure solution and refinement; University of Göttingen: Germany, 1997.

43. Sheldrick, G. M. SHELXTL NT Crystal Structure Analysis Package, Version 5; Bruker AXS Analytical X-ray System: WI (USA), 1999.

\section{License and Terms}

This is an Open Access article under the terms of the Creative Commons Attribution License

(http://creativecommons.org/licenses/by/2.0), which permits unrestricted use, distribution, and reproduction in any medium, provided the original work is properly cited.

The license is subject to the Beilstein Journal of Organic Chemistry terms and conditions:

(http://www.beilstein-journals.org/bjoc)

The definitive version of this article is the electronic one which can be found at: doi:10.3762/bjoc. 10.99 